\title{
Paracrine control of glucagon release by somatostatin (Review)
}

\author{
WILLY J. MALAISSE \\ Department of Biochemistry, Université Libre de Bruxelles, B-1070 Brussels, Belgium
}

Received November 25, 2013; Accepted December 17, 2013

DOI: $10.3892 / \mathrm{ijmm} .2013 .1605$

\begin{abstract}
Emphasis was recently placed on the modulation of glucagon secretion attributable to a paracrine effect of somatostatin. This review draws attention to prior findings related to such a view. The effects of nutrient secretagogues upon insulin, somatostatin and glucagon release by the perfused pancreas are first considered. Three examples of paradoxical secretory responses of insulin- and glucagon-producing cells are then given. Further experiments dealing with the possible role of somatostatin upon glucagon release and the relevance of pancreatic compartmentation are also presented. It is concluded that these prior findings provide, within limits, support to the postulated paracrine role of somatostatin in the control of glucagon secretion.
\end{abstract}

\section{Contents}

1. Introduction

2. Hormonal response of the perfused pancreas to nutrient secretagogues

3. Paradoxical secretory responses of insulin- and glucagonproducing cells

4. Modulatory role of somatostatin upon glucagon release: further experiments

5. Pancreas compartmentation

6. Concluding remarks

\section{Introduction}

In two articles recently published in Diabetes, emphasis was placed on the modulation of glucagon secretion attributable to

Correspondence to: Professor Willy J. Malaisse, Department of Biochemistry, Université Libre de Bruxelles, Route de Lennik 808, B-1070 Brussels, Belgium

E-mail: malaisse@ulb.ac.be

Key words: insulin, somatostatin and glucagon secretion, nutrient secretagogues, paradoxical secretory responses, pancreatic compartmentation a paracrine effect of somatostatin under selected experimental conditions $(1,2)$. In the present review, attention is drawn to prior publications compatible with such a view, but not cited in the two recent articles.

\section{Hormonal response of the perfused pancreas to nutrient secretagogues}

A rise in D-glucose concentration (e.g., from 3.3 to $8.3 \mathrm{mM}$ ) stimulates both insulin and somatostatin release, but inhibits glucagon secretion (3). It should be stressed that, in response to such a rise in D-glucose concentration, an oscillatory pattern of insulin release was documented, the duration of each secretory cycle averaging $5.0 \pm 0.3 \mathrm{~min}(3)$. As a matter of fact, after the rise in D-glucose concentration, up to 8 successive secretory peaks were identified in both insulin and glucagon output, with a virtually identical time course for each of these two hormones (4). Under the same experimental conditions, the stimulation of somatostatin output in response to the rise in D-glucose concentration again displayed an oscillatory pattern, the time course of which was closely similar to that of insulin release (5).

In considering the opposite response of insulin- and glucagon-producing cells to the rise in D-glucose concentration, differences in the metabolic behaviour of these two cell types should not be ignored, as documented by the few following examples. First, whereas in purified pancreatic islet single B-cells (>95\% B-cells) first preincubated in a glucose-free medium the exposure to D-glucose or its non-metabolizable analog 3-O-methyl-D-glucose $(0.6 \mathrm{mM})$ results within $2 \mathrm{~min}$ in the equilibration of their concentration across the plasma membrane, $>30 \mathrm{~min}$ are required to reach a comparable situation in non-B-cells ( $>85 \%$ A-cells and $<3 \%$ B-cells) (6). This coincides with the fact that D-mannoheptulose $(10.0 \mathrm{mM})$ decreases by $50 \%$ or more the conversion of $\mathrm{D}-\left[5-{ }^{3} \mathrm{H}\right]$ glucose to ${ }^{3} \mathrm{HOH}$ and that of D-[U- $\left.{ }^{14}\right]$ glucose to ${ }^{14} \mathrm{CO}_{2}$ and ${ }^{14} \mathrm{C}$-labelled amino acids in purified $\mathrm{B}$-cells, whilst the heptose fails to affect significantly D-glucose metabolism in non-B islet cells (7). Second, the relationship between $\mathrm{D}-\left[\mathrm{U}-{ }^{14} \mathrm{C}\right]$ glucose oxidation and extracellular D-glucose concentration displays a typical sigmoidal pattern in B-cells, as distinct from a hyperbolic pattern in non-B islet cells (6). A closely comparable situation prevails in terms of the increase in $\mathrm{NAD}(\mathrm{P}) \mathrm{H}$ fluorescence at increasing concentrations of D-glucose in $\mathrm{B}$ and non-B islet cells $(8,9)$. Moreover, a rise in $\mathrm{D}$-glucose concentration from 
2.8 to $16.7 \mathrm{mM}$ results in a preferential stimulation of D-glucose oxidation relative to glycolysis in islet B-cells, but not so in purified non-B islet cells (10), the difference if any between these two cell types in terms of the concerned enzymatic activities (hexokinase isoenzymes, cytosolic NAD-linked glycerophosphate dehydrogenase, mitochondrial FAD-linked glycerophosphate dehydrogenase and lactate dehydrogenase) remaining a matter of debate (11). Last, the possible relevance of changes in redox state to the control of glucagon release, as distinct from insulin secretion, in response to a rise or fall in extracellular D-glucose concentration was questioned in the light of a study dealing inter alia with the effect of menadione upon insulin and glucagon output from the perfused rat pancreas (12). Indeed, whilst menadione $(25 \mu \mathrm{M})$ severely impaired the stimulation of insulin release in response to a rise in D-glucose concentration from 3.3 to $11.1 \mathrm{mM}$, the same rise in D-glucose concentration inhibited to the same extent glucagon output whether in the absence or presence of menadione. At the most, in the latter case, the inhibition of glucagon output appeared less abrupt that in the absence of menadione and persisted even after restoration of a low D-glucose concentration. Nevertheless, when the same experiments were conducted in the presence of $10.0 \mathrm{mM}$ arginine throughout the perfusion period, menadione (10 or $25 \mu \mathrm{M})$ administered from the 40th min onwards increased in a rapid and sustained manner glucagon output, whilst failing to prevent the rapid and sustained later decrease in glucagon output recorded in response to a rise in D-glucose concentration initiated $15 \mathrm{~min}$ after the introduction of menadione (12).

In addition to the already mentioned occurrence of synchronized secretory cycles in insulin, somatostatin and glucagon responses to a rise in D-glucose concentration, the anomeric specificity of such a secretory response is also identical in these three islet cell types, as first documented in a report published in 1987 (13). The relevant experiments were performed in the perfused pancreas of 6 lean (192 $\pm 9 \mathrm{~g}$ body wt.) and 6 obese $(284 \pm 19$ g) Zucker rats. The perfusate contained L-leucine $(10.0 \mathrm{mM})$ throughout the experiment. In each type of rat, 3 animals received the D-glucose anomers ( $3.3 \mathrm{mM}$ for $15 \mathrm{~min})$ in an $\alpha 1-\beta 1-\alpha 2-\beta 2$ sequence ( $\alpha 1$ referring to the first administration of $\alpha$-D-glucose, and $\alpha 2$ to its second administration) and the 3 other rats in the opposite order $(\beta 1-\alpha 1-\beta 2-\alpha 2)$. No significant difference between lean and obese rats was found for the pancreas wet weight, its somatostatin content, the basal somatostatin output and the integrated somatostatin release during the entire experiment. The interpretation of secretory data took into account the priming action of D-glucose upon hormonal output as resulting from the repeated administration of the hexose. For such a purpose, the $\alpha 1 / \beta 1$ and $\alpha 2 / \beta 2$ ratios in hormonal secretion recorded in the $\alpha 1-\beta 1-\alpha 2-\beta 2$ series were compared, respectively, to the $\beta 1 / \alpha 1$ and $\beta 2 / \alpha 2$ ratios found in the $\beta 1-\alpha 1-\beta 2-\alpha 2$ series. The ratios recorded in the latter series were eventually expressed relative to the mean values found at the same time and in the same type of animals (lean or obese) in the former series. The biphasic stimulation of insulin and somatostatin release yielding for the $\beta 1 / \alpha 1$ and $\beta 2 / \alpha 2$ ratios in the $\beta 1-\alpha 1-\beta 2-\alpha 2$ series mean values of $38.6 \pm 4.3 \%(n=12)$ for insulin and $56.9 \pm 9.4 \%(n=10)$ for somatostatin, both significantly lower ( $\mathrm{p}<0.02$ or less) than the corresponding reference values for the $\alpha 1 / \beta 1$ and $\alpha 2 / \beta 2$ ratios in the $\alpha 1-\beta 1-\alpha 2-\beta 2$ series, i.e., $100.0 \pm 6.0 \%(n=12)$ and $100.0 \pm 11.5 \%(n=12)$ for insulin and somatostatin, respectively. Likewise, in the case of the inhibitory action of D-glucose upon glucagon release, the $\beta / \alpha$ ratios averaged in the $\beta 1-\alpha 1-\beta 2-\alpha 2$ series $48.9 \pm 5.6 \%(n=10)$ as distinct $(\mathrm{p}<0.001)$ from $100.0 \pm 10.7 \%(\mathrm{n}=12)$ for the $\alpha / \beta$ ratios in the $\alpha 1-\beta 1-\alpha 2-\beta 2$ series. The identical anomeric specificity of this triple secretory response was considered compatible, in terms of the metabolic regulation of hormonal release, with a coordinated behaviour of all islet cells (13).

Like D-glucose, 2-ketoisocaproate (10.0 mM), when administered for $25 \mathrm{~min}$ to pancreases exposed throughout the experiments to $3.3 \mathrm{mM}$ D-glucose, provoked both a biphasic and rapidly reversible stimulation of insulin release and sustained inhibition of glucagon output (14). Such was also the case when the pancreases were exposed to both D-glucose (3.3 $\mathrm{mM})$ and arginine (10.0 $\mathrm{mM})(14)$. Yet, L-leucine, which is a major metabolite generated from 2-ketoisocaproate in rat isolated pancreatic islets (15), stimulates both insulin and glucagon secretion, as well as somatostatin output, whether at low $(3.3 \mathrm{mM})$ or normal $(8.3 \mathrm{mM}) \mathrm{D}$-glucose concentration and, at each of these two hexose concentrations, whether in the absence or presence of arginine $(5.0 \mathrm{mM})(16)$. Whether at low or normal D-glucose concentration and whether in the absence or presence of arginine, the magnitude of the secretory responses of both insulin- and glucagon-producing cells to the branched chain amino acid is concentrated-related in the range between 0.2 and $15.0 \mathrm{mM}$ L-leucine (16). In these experiments, an inhibitory component of the secretory response of glucagon-producing cells to L-leucine was only observed after an initial secretory peak in pancreases exposed to $3.3 \mathrm{mM}$ D-glucose in the presence of $5.0 \mathrm{mM}$ arginine, the magnitude of the latter inhibitory effect being also progressively increased as the concentration of L-leucine was raised from 0.2 to 5.0 and $15.0 \mathrm{mM}$ (16).

Several other amino acids also stimulate both insulin and glucagon secretion, as well as somatostatin output whenever measured. For instance, the administration of arginine $(5.0 \mathrm{mM})$ to perfused rat pancreases evokes a biphasic and sustained increase in the output of all these three pancreatic hormones (16). The secretory response of both insulin- and somatostatin-producing cells to arginine is much greater at 8.3 than at $3.3 \mathrm{mM} \mathrm{D}$-glucose, whilst a mirror image prevails for the stimulation of glucagon output by arginine. The positive secretory response to L-arginine $(5.0 \mathrm{mM})$ by rat pancreases exposed throughout the experiment to $8.3 \mathrm{mM}$ D-glucose displays an oscillatory pattern, with a time course for the 5 to 9 first cycles undistinguishable for insulin and somatostatin, respectively (17). Moreover, within the same series of experiments, the stimulation of glucagon output by L-arginine $(5.0 \mathrm{mM})$ in pancreases exposed throughout to $3.3 \mathrm{mM}$ D-glucose was again characterized in 5 individual experiments by an oscillatory pattern, the first 5 to 8 glucagon secretory cycles yielding a mean duration of 5.6 $\pm 0.4 \mathrm{~min}$ $(n=37)(17)$.

L-glutamine $(10.0 \mathrm{mM})$ also provokes a biphasic stimulation of glucagon output, at least in the absence of D-glucose (16). In the same experiments, the biphasic increase in insulin output provoked by L-leucine $(15.0 \mathrm{mM})$ was approximately $4-5$-fold higher in the presence of L-glutamine $(10.0 \mathrm{mM})$ and absence of D-glucose than in the presence of both $3.3 \mathrm{mM}$ D-glucose and $5.0 \mathrm{mM}$ arginine. Under these two experimental condi- 
tions, a severe inhibition of glucagon output prevailed a few minutes after initiating the administration of $15.0 \mathrm{mM}$ L-leucine (16).

In the presence of $5.6 \mathrm{mM} \mathrm{D}$-glucose, L-ornithine $(10.0 \mathrm{mM})$ duplicates the effect of L-arginine (also $10.0 \mathrm{mM}$ ) in causing a biphasic and rapidly reversible stimulation of insulin, somatostatin and glucagon release from rat perfused pancreases (18). These and complementary findings suggested that the secretory response to L-arginine and L-ornithine involved mainly a biophysical component, such as the depolarization of the plasma membrane by these cationic amino acids.

The dimethyl ester of glutamic acid (10.0 mM) also provokes a rapid and sustained increase in both insulin and glucagon output from rat pancreases exposed to $6.0 \mathrm{mM}$ D-glucose, followed in both cases by a transient 'off' response when the administration of the ester is halted (19).

Last, a mixture of fumarate, glutamine and pyruvate (5.0 $\mathrm{mM}$ each), currently used to supply energy in isolated tissues, was found to provoke a biphasic stimulation of both insulin and glucagon release by perfused rat pancreases (20). The magnitude of the insulin secretory response to this FGP mixture was much greater at $16.6 \mathrm{mM}$ D-glucose than at $3.3 \mathrm{mM}$ D-glucose, with a mirror image for the response of glucagon-producing cells to the same mixture. The secretory response to the FGP mixture resembled that evoked, within the same series of experiments, by arginine $(10.0 \mathrm{mM})$ with, however, three obvious differences. First, whilst arginine provoked an obvious biphasic and rapidly reversible increase in insulin output in the presence of $3.3 \mathrm{mM}$ D-glucose, only a sluggish and quite modest increase in insulin output was observed in response to the administration of FGP mixture at the same low concentration of D-glucose. Second, in contrast to the rapid reversibility of the glucagon secretory response to arginine, at the same low D-glucose concentration $(3.3 \mathrm{mM})$, the heightened glucagon output caused by the FGP mixture persisted for some 3 min after the arrest of the FGP infusion. Third, in the experiments conducted at $16.6 \mathrm{mM}$ D-glucose, the insulin output slowly lowered down towards the control values over the $5 \mathrm{~min}$ following the arrest of the FGP infusion, whilst a profound inhibition of insulin release occurred upon arrest of the arginine infusion. In the latter case, $>20 \mathrm{~min}$ were required for the output of insulin to reach close to control values (20).

\section{Paradoxical secretory responses of insulin- and glucagon-producing cells}

In some of the investigations either so far or later reviewed in this article, it may not be easy to distinguish between the respective roles of insulin and somatostatin in the postulated paracrine control of glucagon release. It seems worthwhile, therefore, to consider three instances in which a possible cause-to-effect link between changes in insulin and glucagon secretion was not obvious.

A first obvious dissociation between the response of insulin- and glucagon-producing cells to a rise in D-glucose concentration was observed in the perfused rat pancreas first perfused for $85 \mathrm{~min}$ at $5.6 \mathrm{mM}$ D-glucose and then exposed up to min 100 to $16.7 \mathrm{mM}$ D-glucose (21). Thus, in the control experiments, such a late rise in D-glucose concentration provoked the expected biphasic stimulation of insulin release and concomitant decrease in glucagon output. However, when either glibenclamide or glimepiride $(0.1 \mu \mathrm{M}$ each) was administered from the 41st to 60th min, resulting in a biphasic stimulation of insulin release which persisted up to the 85 th min, the later rise in D-glucose concentration from 5.6 to $16.7 \mathrm{mM}$ ( 86 to $100 \mathrm{~min}$ ) again provoked a biphasic increase of insulin secretion displaying a comparable time course and magnitude as in the control experiments. Yet, under the same experimental conditions, the modest inhibition of glucagon output caused by the administration of the hypoglycemic sulfonylurea (41 to $60 \mathrm{~min}$ ) coincided with the fact that the late rise in D-glucose concentration did no more result in any inhibition of glucagon output, in sharp contrast to the results recorded in the control experiments. It was speculatively proposed that the sulfonuylurea-induced changes in glucagon output might result from some paracrine effect (21).

In a further study, another example of paradoxical secretory responses of insulin- and glucagon-producing cells to selected secretagogues was observed in experiments conducted in the perfused pancreas of rats rendered hyperglycemic by a prior 48 -h infusion of D-glucose $(1.67 \mathrm{M})$ at a rate close to $4.6 \mathrm{mmol}$ D-glucose per hour (22). In these rats, in mirror image of findings made in control euglycemic rats, a decrease in D-glucose concentration from 16.7 to $2.8 \mathrm{mM}$ provoked a paradoxical stimulation of insulin output, which was rapidly suppressed when a high concentration of the hexose $(16.7 \mathrm{mM})$ was later restored. This coincided with the absence of any sizeable change in glucagon output whether in response to the initial decrease in D-glucose concentration from 16.7 to $2.8 \mathrm{mM}$ or the later rise in such a concentration from 2.8 o $16.7 \mathrm{mM}$, at variance with the expected stimulation of glucagon secretion recorded in response to the initial fall in D-glucose concentration and its suppression in response to the later rise in hexose concentration indeed observed in the perfused pancreas prepared from control euglycemic rats. In sharp contrast to these findings, the administration of 2-ketoisocaproate $(10.0 \mathrm{mM}) 10 \mathrm{~min}$ after the initial fall in D-glucose concentration caused a rapid, sustained and rapidly reversible increase of both insulin and glucagon secretion in the pancreas of glucose-infused rats comparable to that observed, under the same experimental conditions in the pancreas of control euglycemic rats (22). It should be underlined that, when the pancreases from the glucose-infused rats were first exposed for $55 \mathrm{~min}$ to $2.8 \mathrm{mM} \mathrm{D}$-glucose, a rise in the concentration of the hexose to $16.7 \mathrm{mM}$ caused both a biphasic stimulation of insulin release and a significant decrease in glucagon output (23). The paradoxical increase in insulin output recorded in the pancreas from glucose-infused rats in response to a fall in D-glucose concentration, which is also observed in perifused islets prepared from glucoseinfused rats (24), was eventually found attributable to an interference of glycogenolysis with glycolysis in the pancreatic islets from glucose-infused rats $(24,25)$.

A third dissociation between the secretory response of insulin- and glucagon-producing cells emerged from the control experiments conducted in the pancreas of euglycemic rats in the same study (22). Thus, as just mentioned, in the pancreas of control euglycemic rats the administration of 2-ketoisocaproate $(10.0 \mathrm{mM})$ initiated $10 \mathrm{~min}$ after the decrease in D-glucose concentration from 16.7 to $2.8 \mathrm{mM}$ provoked a 
biphasic stimulation of both insulin and glucagon output. These results sharply contrast with those otherwise recorded in the pancreas of euglycemic rats when 2-ketoisocaproate $(10.0 \mathrm{mM})$ is administered from the 41 st to 65 th min of the experiment to pancreases exposed throughout the perfusion period to $3.3 \mathrm{mM}$ D-glucose (14). In such a case, the biphasic stimulation of insulin release by 2-ketoisocaproate coincides with a dramatic and sustained inhibition of glucagon output. In considering these contrasting changes in the secretory response to 2-ketoisocaproate of glucagon-producing cells, the following remarks should not be ignored. First, prior to the administration of 2-ketoisocaproate (i.e., from 26 to $35 \mathrm{~min}$ ), the output of glucagon averaged $119 \pm 18 \mathrm{pg} / \mathrm{min}(\mathrm{n}=9)$ in the control experiments conducted in euglycemic rats, i.e., after the fall in D-glucose concentration from 16.7 to $2.5 \mathrm{mM}$ at the 25 th $\mathrm{min}$ of the experiments, as distinct from $890 \pm 90 \mathrm{pg} / \mathrm{min}$ $(n=4)$ in the experiments conducted throughout at $3.3 \mathrm{mM}$ D-glucose in the pancreas of euglycemic rats. These two sets of experiments differed from one another by the extremely high D-glucose concentration $(16.7 \mathrm{mM})$ used during the first 25 min of perfusion in the control experiments conducted in euglycemic rats and the extremely low D-glucose concentration $(3.3 \mathrm{mM})$ used during the first $40 \mathrm{~min}$ of perfusion in the second set of experiments. Second, the glucagon secretory rate recorded during exposure of the pancreas to 2-ketoisocaproate was comparable in the control experiments conducted in euglycemic rats $(349 \pm 62 \mathrm{pg} / \mathrm{min} ; \mathrm{n}=3)$ and in the experiments conducted throughout in the presence of $3.3 \mathrm{mM} \mathrm{D}$-glucose $(210 \pm 60 \mathrm{pg} / \mathrm{min} ; \mathrm{n}=4)$. Last, it is conceivable that the low cytosolic $\mathrm{Ca}^{2+}$ concentration presumably associated with the low output of glucagon in the pancreases first exposed for $25 \mathrm{~min}$ to a high concentration of D-glucose somehow adversely affected the normal inhibitory effect of 2-ketoisocaproate upon glucagon release. Indeed, a lowering of extracellular $\mathrm{Ca}^{2+}$ concentration is known to also provoke a dramatic increase in glucagon output from pancreases perfused in the presence of 2-ketoisocaproate (26).

\section{Modulatory role of somatostatin upon glucagon release: further experiments}

A further observation consistent with a modulatory role of somatostatin upon glucagon output emerged from experiments dealing with the secretory response of the perfused rat pancreas to L-leucine examined at different D-glucose levels and in the absence or presence of L-arginine (16).

First, whilst at $3.3 \mathrm{mM}$ D-glucose, the administration of arginine $(5.0 \mathrm{mM})$ only provoked a minor increase in somatostatin output, the response to arginine at $8.3 \mathrm{mM} \mathrm{D}$-glucose consisted in a dramatic and sustained increase in somatostatin output. This coincided with the fact that, at $3.3 \mathrm{mM}$ D-glucose, arginine provoked an ample and biphasic stimulation of glucagon output, whilst at $8.3 \mathrm{mM}$ D-glucose only a minor and transient increase of glucagon output was observed in response to arginine. Incidentally, in these experiments, the relative magnitude of changes provoked by arginine in insulin output was closely comparable to those recorded for somatostatin output (16).

Likewise, in response to the administration of L-leucine $(15.0 \mathrm{mM})$, the release of somatostatin was barely increased at $3.3 \mathrm{mM}$ D-glucose, whilst an ample, rapid and sustained increase of somatostatin secretion was provoked by L-leucine at $8.3 \mathrm{mM}$ D-glucose. This again coincided with the fact that, at $3.3 \mathrm{mM}$ D-glucose, L-leucine $(15.0 \mathrm{mM})$ increased glucagon output to $734 \pm 86 \%$ (early period of exposure to L-leucine, 3 to $6 \mathrm{~min}$ ) and $244 \pm 45 \%$ (late period, ensuing $9 \mathrm{~min}$ ) of paired reference values recorded $1 \mathrm{~min}$ before administration of the branched chain amino acid, whilst at $8.3 \mathrm{mM} \mathrm{D}$-glucose the corresponding percentages did not exceed $173 \pm 36 \%$ (early period) and $124 \pm 32 \%$ (late period), the latter two percentages failing to differ significantly from the $100 \%$ reference value (paired comparison). Once again, in these experiments the pattern of changes provoked by L-leucine in insulin output were comparable to those recorded for somatostatin output (16).

Moreover, when L-leucine $(15.0 \mathrm{mM})$ was administered for $15 \mathrm{~min}$ during exposure to L-arginine $(5.0 \mathrm{mM})$, the release of somatostatin reached mean values 6 to 7 -fold higher at $8.3 \mathrm{mM}$ D-glucose than at $3.3 \mathrm{mM}$ D-glucose. This again coincided with the fact that, under the same experimental conditions, the positive response of glucagon-producing cells to the branchedchain amino acid was close to the limit of detection at $8.3 \mathrm{mM}$ D-glucose, whilst being virtually identical to that evoked, within the same experiments, by L-leucine in the absence of arginine and sole presence of $3.3 \mathrm{mM}$ D-glucose. As expected, the secretory response of insulin-producing cells to L-leucine, as recorded in the presence of $5.0 \mathrm{mM}$ arginine, was about 10 -fold higher at $8.3 \mathrm{mM}$ D-glucose than at $3.3 \mathrm{mM}$ D-glucose. It should not be ignored that in the experiments conducted in the presence of both $3.3 \mathrm{mM}$ D-glucose and $5.0 \mathrm{mM} \mathrm{L}$-arginine, the return of somatostatin output to basal value recorded after removal of L-leucine from the perfusate coincided with an obvious increase of glucagon output, the latter two processes displaying a superimposable time course (16).

In the same series of experiments, further relevant information was gathered on the modulation by D-glucose and arginine of the secretory response of glucagon-producing cells to L-leucine. First, at $3.3 \mathrm{mM}$ D-glucose, the early peak response of glucagon-producing cells progressively increased as the concentration of L-leucine was raised from 0.2 to 2.0 and $15.0 \mathrm{mM}$. Such was also the case in the concomitant presence of $3.3 \mathrm{mM}$ D-glucose and $5.0 \mathrm{mM}$ arginine. However, in the latter case, i.e., in the presence of arginine, the output of glucagon after the early peak returned to the same level as that found before administration of $2.0 \mathrm{mM}$ L-leucine and was obviously much lower than that recorded before administration of $15.0 \mathrm{mM}$ L-leucine. This coincided with a progressive increase in the relative magnitude of the increment in insulin output provoked by L-leucine $(0.2,2.0$ and $15.0 \mathrm{mM}$ ) in the presence of both $3.3 \mathrm{mM}$ D-glucose and $5.0 \mathrm{mM}$ arginine. An inhibitory component of the secretory response of glucagon-producing cells to L-leucine was even more pronounced when the pancreas was eventually perfused in the absence of D-glucose but presence of L-glutamine (10.0 mM). Under these experimental conditions, L-glutamine provoked a biphasic stimulation of glucagon output. However, when L-leucine $(15.0 \mathrm{mM})$ was administered in the presence of L-glutamine, an immediate, sustained and reversible virtually total suppression of glucagon output was observed. This coincided with the fact that, after a short-lived peak response of insulin-producing cells to the introduction of L-glutamine, 
the later administration of L-leucine provoked a dramatic biphasic and reversible stimulation of insulin secretion. Thus, despite the absence of D-glucose, the magnitude of the changes in insulin output caused by L-leucine $(15.0 \mathrm{mM})$ in the presence of L-glutamine $(10.0 \mathrm{mM})$ was about twice higher than those recorded within the same experiment in response to a rise in D-glucose concentration from 3.3 to $8.3 \mathrm{mM}$ (16).

In another study, D-mannoheptulose $(1.7 \mathrm{mM})$, thought to be transported into cells at the intervention of GLUT2, was found to inhibit insulin release and, in most cases, somatostatin output, whereas it augmented glucagon secretion by pancreases exposed to D-glucose (3.3 mM) in the presence of the dimethyl ester of succinic acid (SAD, $10.0 \mathrm{mM}$ ). The heptose failed, however, to affect hormonal secretion in the sole presence of SAD. These findings are consistent with the postulated paracrine effect of somatostatin upon glucagon output (27).

In the concomitant presence of $3.3 \mathrm{mM}$ D-glucose and $10.0 \mathrm{mM}$ SAD, the hexacetate ester of D-mannoheptulose $(1.7 \mathrm{mM})$ first provoked a transient decrease in somatostatin output. Thereafter, however, the somatostatin secretory rate reached a mean value about twice higher and, as such, no more significantly different from basal value. Likewise, in the case of insulin release, a partial relief of the early inhibitory action of D-mannoheptulose hexaacetate upon insulin output was observed, it being maximal 5 min after the introduction of the ester. The latter finding could suggest the occurrence of a modest stimulatory component in the action of the heptose ester upon insulin release. Nevertheless, when halting the administration of D-mannoheptulose hexaacetate, a rebound of insulin secretory rate was observed, comparable to that otherwise recorded after removal of unesterified D-mannoheptulose from the perifusate. The response of glucagon-producing cells to D-mannoheptulose hexaacetate administered to pancreases exposed to both $3.3 \mathrm{mM}$ D-glucose and 10.0 mM SAD was essentially comparable to that observed in response to unesterified D-mannoheptulose (27).

In pancreases exposed to SAD in the absence of D-glucose, the effects of D-mannoheptulose hexaacetate upon the secretion of all three pancreatic hormones differed from that otherwise recorded in the concomitant presence of SAD and D-glucose. First, a transient increase in insulin output was first observed, it corresponding in its time course to the relief from the inhibition of insulin release caused by D-mannoheptulose hexaacetate in the presence of both SAD and D-glucose. A rebound in insulin output was observed after removal of D-mannoheptulose hexaacetate from the perfusate in the experiments conducted in the sole presence of SAD, it being comparable to that found in the presence of both D-glucose and SAD. The release of somatostatin underwent a pronounced and progressive stimulation by D-mannoheptulose hexaacetate in the experiments conducted in the sole presence of SAD. Such a stimulation was reversible, the somatostatin secretory rate returning progressively to basal value when the administration of the esterified heptose was halted. Last, at variance with the failure of unesterified D-mannoheptulose to affect glucagon release from pancreases exposed to SAD in the absence of D-glucose, the results recorded in response to the administration of the esterified heptose were compatible with a modest but significant rapid, sustained and rapidly reversible stimulation of glucagon output comparable to that otherwise observed in response to the administration of D-mannoheptulose hexaacetate in pancreases exposed to both SAD and D-glucose. Taken as a whole, the findings made with D-mannoheptulose hexaacetate support the view that monosaccharide esters may affect the secretion of pancreatic hormones in a dual manner with, on occasion, e.g. in the sole presence of SAD, prevalent stimulation of both somatostatin and glucagon output (27). In all these experiments, the functional integrity of the endocrine pancreas was assessed by administration of L-arginine $(5.0 \mathrm{mM})$ at the end of the perfusion period. A biphasic stimulation of both insulin and somatostatin release and a monophasic stimulation of glucagon release by arginine were observed in all cases.

A mirror image in terms of the changes in somatostatin and glucagon output was also observed when considering the effect of 2-deoxy-D-glucose $(1.7$ and $8.5 \mathrm{mM})$ in pancreases perfused in the presence of $8.3 \mathrm{mM} \mathrm{D-glucose}$. Thus, 2-deoxyD-glucose provoked a concentration-related inhibition of both insulin and somatostatin release. At $8.5 \mathrm{mM} 2$-deoxyD-glucose, somatostatin secretion was totally suppressed and this coincided with a sizeable increase in glucagon output (28). Both the inhibition of somatostatin release and enhancement of glucagon secretion were rapidly reversed upon removal of 2-deoxy-D-glucose from the perfusate. The same study also provided further evidence that the same secretagogue may simultaneously stimulate the release of all three pancreatic hormones. It was indeed observed that both the $\alpha$ - and $\beta$-anomer of 2-deoxy-D-glucose tetracetate, tested at 1.7 and $8.5 \mathrm{mM}$ concentration, caused a concentration-related stimulation of insulin, somatostatin and glucagon output (28).

In another study conducted in the isolated perfused rat pancreas exposed to $3.3 \mathrm{mM}$ D-glucose throughout the experiment, the eventual stimulation of somatostatin release by arginine $(5 \mathrm{mM})$ between the 73rd and 90th min of the experiment was more markedly increased in response to a prior exposure (37 $\mathrm{min}$ to $50 \mathrm{~min}$ ) to D-fructose $(17$ or $40 \mathrm{mM}$ ) than in response to a prior exposure (also 37 to $50 \mathrm{~min}$ ) to D-glucose (5.0 or $7.3 \mathrm{mM}$ ), despite the fact that during the first stimulatory period (37 to $50 \mathrm{~min}$ ) the insulin output was comparable at either 5.0 mM D-glucose or $17.0 \mathrm{mM} \mathrm{D}$-fructose and at either $7.3 \mathrm{mM}$ D-glucose or $40 \mathrm{mM}$ D-fructose. This coincided with the fact that the prior exposure to D-fructose significantly decreased the arginine-induced stimulation of glucagon release (73 to $90 \mathrm{~min}$ ), when comparing the results recorded after a prior exposure $(37$ to $50 \mathrm{~min})$ to either 5.0 mM D-glucose versus $17.0 \mathrm{mM}$ D-fructose or $7.3 \mathrm{mM}$ $\mathrm{D}$-glucose versus $40.0 \mathrm{mM} \mathrm{D}$-fructose. Incidentally, in these experiments, the stimulation of insulin output during the first stimulation period ( 37 to $50 \mathrm{~min}$ ) failed to achieve statistical significance at either 5.0 mM D-glucose or $17 \mathrm{mM}$ D-fructose, whilst displaying a typical biphasic pattern at either $7.3 \mathrm{mM}$ D-glucose or $40.0 \mathrm{mM}$ D-fructose. Likewise, the mean absolute values for glucagon output during the first period of stimulation, which were invariably lower than those recorded during the initial basal period, were comparable at $5.0 \mathrm{mM}$ D-glucose versus $17.0 \mathrm{mM}$ D-fructose and at $7.3 \mathrm{mM}$ D-glucose versus 40.0 mM D-fructose (29).

A more sophisticated view concerning the possible link between somatostatin and glucagon secretion emerged from a study dealing with the effects of $\alpha$-D-glucose pentaacetate and $\beta$-L-glucose pentaacetate $(1.7 \mathrm{mM}$ each) administered to 
pancreases perfused throughout the experiment in the presence of L-leucine $10 \mathrm{mM}$ (30).

The insulin secretory response (2 to $53 \mathrm{~min}$ ) differed vastly with the three secretagogues under consideration. Thus the administration of $\alpha$-D-glucose pentaacetate $(1.7 \mathrm{mM})$ resulted in a rapid and biphasic increase in insulin output, with an oscillatory pattern after the initial secretory peak and a rapid reversion when $\alpha$-D-glucose pentaacetate was removed from the perfusate. The administration of $\beta$-L-glucose pentaacetate (also $1.7 \mathrm{mM}$ ) only provoked a delayed and quite modest increase in insulin release. Thus the mean output of insulin during exposure to $\beta$-L-glucose pentaacetate $(29$ to $53 \mathrm{~min}$ inclusive) averaged no more than $0.43 \pm 0.05 \mathrm{ng} / \mathrm{min}$, as distinct from $6.98 \pm 1.54 \mathrm{ng} / \mathrm{min}$ in the case of $\alpha$-D-glucose pentaacetate. Last, the administration of unesterified D-glucose (1.7 mM) did not affect significantly insulin output (30).

The somatostatin secretory response also differed vastly with the three secretagogues under consideration. Both $\alpha$-D-glucose pentaacetate and $\beta$-L-glucose pentaacetate provoked a progressive increase in somatostatin output, without any obvious early secretory peak, the output of somatostatin rapidly resuming basal values after removal of the pentaacetate esters from the perfusate. The magnitude of the somatostatin positive secretory response was significantly lower $(\mathrm{p}<0.005)$ in the case of $\beta$-L-glucose pentaacetate as distinct from $\alpha$-D-glucose pentaacetate. Once again, unesterified D-glucose (1.7 $\mathrm{mM}$ ) failed to augment somatostatin output (30).

Last in the case of glucagon output, only unesterified D-glucose provoked an immediate decrease in glucagon secretion. Inversely, the pentaacetate esters provoked an immediate peak-shaped stimulation of glucagon output. After this early positive glucagon response, no obvious effect of $\beta$-L-glucose pentaacetate upon glucagon secretion was anymore observed. However, in the pancreases exposed to $\alpha$-D-glucose pentaacetate, the early glucagon secretory peak was rapidly followed by a pronounced and sustained inhibition of glucagon output, the latter inhibition being reversed after removal of the $\alpha$-anomer from the perfusate (30).

In all these experiments, the functional integrity of the perfused pancreases was assessed at the end of the experiments by monitoring the secretory response to $5.5 \mathrm{mM}$ unesterified D-glucose. In all cases, the hexose evoked a biphasic increase in insulin output, with typical oscillations during the early phase of stimulation. No significant difference in such an insulin secretory response to unesterified D-glucose was observed when comparing the results recorded after a prior exposure to either $\alpha$-D-glucose pentaacetate, $\beta$-L-glucose pentaacetate or unesterified D-glucose. Likewise, the administration of unesterified D-glucose $(5.5 \mathrm{mM})$ at the end of the experiments always provoked a biphasic increase in somatostatin output, with again an oscillatory pattern following the early secretory peak. In absolute terms ( $\mathrm{pg} / \mathrm{min})$, the somatostatin secretory response to unesterified D-glucose $(5.5 \mathrm{mM})$ was higher in the pancreases first exposed to $\alpha$-D-glucose pentaacetate or $\beta$-L-glucose pentaacetate as compared to unesterified D-glucose. Last, the administration of unesterified D-glucose $(5.5 \mathrm{mM})$ at the end of the experiments always resulted in a rapid and significant decrease in glucagon output, demonstrating the metabolic and functional integrity of the glucagon-producing cells. The relative extent of the inhibitory action of unesterified D-glucose $(5.5 \mathrm{mM})$ on glucagon release was somewhat more pronounced $(\mathrm{p}<0.05)$ after prior exposure to $\alpha$-D-glucose pentaacetate than after prior exposure to either $\beta$-L-glucose pentaacetate or unesterified D-glucose (30).

Although these findings confirm that some secretagogues may exert a dual, both stimulatory and inhibitory effect on glucagon release, they provide further support for the immediate and delayed (memory phenomenon) paracrine modulation of glucagon output by somatostatin. Indeed, the pronounced inhibition of glucagon output observed during the late period of exposure of the pancreas to $\alpha$-D-glucose pentaacetate and the subsequent reascension of glucagon secretion after removal of the latter ester from the perfusate represented two phenomena not observed in response to the administration of $\beta$-L-glucose pentaacetate and coinciding with a significantly lower output of somatostatin (and insulin) during the late period of exposure of the pancreas to $\beta$-L-glucose pentaacetate as distinct from $\alpha$-D-glucose pentaacetate.

Before concluding this review, a further example of an apparent dissociation between the secretory response of somatostatin and glucagon-producing cells merits to be mentioned. It refers to the effects of two meglitinide analogs, i.e., repaglinide $(0.01 \mu \mathrm{M})$ and A-4166 $(1.0 \mu \mathrm{M})$ in perfused rat pancreases exposed to $5.6 \mathrm{mM} \mathrm{D}$-glucose (31). These two meglitinide analogs stimulated both insulin and somatostatin output (40 to $60 \mathrm{~min}$ ). The time course for such a secretory response was identical for the latter two hormones, but differed when comparing the results recorded upon the administration of either repaglinide or A-4166, with a more sluggish onset and less rapid reversibility with repaglinide than with A-4166. In these experiments, the concentration of D-glucose was eventually raised from 5.6 to $16.7 \mathrm{mM}$ from 86 to $100 \mathrm{~min}$. This resulted again in increases of both insulin and somatostatin output. Such increases were considerably higher than those evoked at 40 to $60 \mathrm{~min}$ by the meglitinide analogs. The paired ratio for insulin output during these two periods was not significantly different in the repaglinide and A-411 experiments, with an overall mean value of $4.6 \pm 0.6 \%(n=8)$. Likewise, the paired ratio for somatostatin output during the 44 to $63 \mathrm{~min}$ period and 89 to $100 \mathrm{~min}$ period was not significantly different in the repaglinide and A-4166 experiments, with an overall mean value of $17.7 \pm 3.8 \%(n=8)$. Incidentally, the time course of the secretory response to the late rise in D-glucose concentration differed in insulin-producing versus somatostatin-producing cells. The glucose-induced increase in insulin release indeed displayed a typical biphasic pattern, whilst the hexose-induced stimulation of somatostatin output became only detectable one min later and progressively increased without any evidence of a biphasic pattern. No obvious effect of either repaglinide or A-4166 upon glucagon output was observed in these experiments, whilst the later rise in D-glucose concentration inhibited significantly glucagon output, the paired ratio between the mean glucagon output at the 99th and 100th min averaging $72.1 \pm 2.2 \%(\mathrm{n}=8 ; \mathrm{p}<0.001)$ of the paired value $(100 \%)$ recorded over the preceding $5 \mathrm{~min}$ period (84-88 min inclusive). These findings emphasize the occasional sophistication of the regulation of hormonal secretion by the endocrine pancreas. They indeed document two examples of dissociated responses of distinct islet cells to a given secretagogue. First, the prior administration of meglitinide analogs disrupted the otherwise 
parallelism between the time course of the secretory response to a rise in D-glucose concentration in insulin-producing cells and somatostatin-producing cells. Second, the present findings once again illustrate that stimulation of somatostatin release, in this case by meglitinide analogs, does not always coincide with inhibition of glucagon output (31).

\section{Pancreas compartmentation}

In all the studies conducted in the perfused rat pancreas and so far reviewed in this article, no attention was paid to the compartmentation of the pancreas. Yet, in the rat, as in other species (e.g., canines and humans), the pancreas is composed of two parts, i.e., the dorsal (or splenic) and ventral (or duodenal) parts. These parts differ from one another inter alia by their embryology, vasculature, exocrine and endocrine cell types.

In a study conducted in rat pancreases (32), the insulin content of the dorsal pancreas $(130 \pm 12 \mu \mathrm{g} / \mathrm{g}$ wet weight) and ventral pancreas $(159 \pm 16 \mu \mathrm{g} / \mathrm{g})$ were not significantly different from one another, whilst the glucagon content was significantly lower $(\mathrm{p}<0.01)$ in the ventral pancreas $(3.3 \pm 0.6 \mu \mathrm{g} / \mathrm{g})$ than in the dorsal pancreas $(8.4 \pm 1.2 \mu \mathrm{g} / \mathrm{g})$. In a first series of experiments, a rise in D-glucose concentration from 3.3 to $8.3 \mathrm{mM}$ was achieved from 41 to $56 \mathrm{~min}$. Arginine $(5.0 \mathrm{mM})$ was then administered from 76 to $130 \mathrm{~min}$. A second rise in D-glucose concentration took place from 91 to $106 \mathrm{~min}$. In response to the two rises in D-glucose concentration, the insulin output was significantly higher in the dorsal than ventral pancreas, whether expressed as $\mathrm{ng} / \mathrm{min}, \mathrm{ng} / \mathrm{ml}$ or relative to the insulin content. Such was also the case in a second series of experiments in which stimulation of insulin release was achieved by the administration of either carbamylcholine $(1.0 \mu \mathrm{M})$ or arginine $(5.0 \mathrm{mM})$ in the presence of $7.0 \mathrm{mM}$ D-glucose. These results indicate that B-cells in the ventral pancreas respond poorly to several stimuli. In the first series of experiments, the rise in D-glucose concentration inhibited glucagon release whether in the absence or presence of arginine, whilst the latter amino acid provoked a pronounced and biphasic increase in glucagon output. In the second series of experiments conducted in the presence of $7.0 \mathrm{mM}$ D-glucose, the administration of carbamylcholine $(1.0 \mu \mathrm{M})$ evoked a biphasic increase in glucagon output, the later administration of arginine $(5.0 \mathrm{mM})$ also stimulating glucagon secretion predominantly during an initial secretory peak. In absolute terms (ng/min) the output of glucagon recorded in the first or second series of experiments was much higher in the dorsal than ventral part of the pancreas. Expressed relative to glucagon content, however, a significantly higher output of glucagon in the dorsal than ventral part of the pancreas was only observed in response to stimulation by arginine at low D-glucose concentration, no significant difference being anymore observed under the other 6 experimental conditions. In other words, the lesser responsiveness of insulin-producing cells in the ventral than dorsal pancreas, failed to coincide with a comparable difference in glucagon-producing cells (32).

\section{Concluding remarks}

The present illustrative but far from exhaustive review provides, within limits, further support to the postulated paracrine role of somatostatin in the modulation of glucagon release under selected experimental conditions.

\section{References}

1. Cheng-Xue R, Gomez-Ruiz A, Antoine N, Noël LA, Chae HY, Ravier MA, Chimienti F, Scuit FC and Gilon P: Tolbutamide controls glucagon release from mouse islets differently than glucose: involvement of K(ATP) channels from both $\alpha$-cells and ठ-cells. Diabetes 62: 1612-1622, 2013.

2. Karimian N, Qin T, Liang T, Osundiji M, Huang Y, Teich T, Riddell MC, Cattral MS, Coy DH, Vranic M and Gaisano HY: Somatostatin receptor type 2 antagonism improves glucagon counterregulation in biobreeding diabetic rats. Diabetes 62: 2968-2977, 2013

3. Leclercq-Meyer V, Considine RV, Sener A and Malaisse WJ: Do leptin receptors play a functional role in the endocrine pancreas? Biochem Biophys Res Commun 229: 794-798, 1996.

4. Leclercq-Meyer V and Malaisse WJ: Failure of leptin to counteract the effects of glucose on insulin and glucagon release by the perfused rat pancreas. Med Sci Res 25: 257-259, 1997

5. Leclercq-Meyer V and Malaisse WJ: Failure of human and mouse leptin to affect insulin, glucagon and somatostatin secretion by the perfused rat pancreas at physiological glucose concentrations. Mol Cell Endocrinol 141: 111-118, 1998.

6. Gorus FK, Malaisse WJ and Pipeleers DG: Differences in glucose handling by pancreatic A- and B-cells. J Biol Chem 259: 1196-1200, 1984.

7. Ramirez R, Jijakli H, Zhang HX, Nadi AB, Sener A and Malaisse WJ: Effects of D-mannoheptulose upon D-glucose metabolism in pancreatic B and non-B islet cells. Int J Mol Med 9: 159-163, 2002.

8. Mercan D and Malaisse WJ: Pancreatic islet B-cell individual variability rather than subpopulation heterogeneity. Mol Cell Endocrinol 118: 163-171, 1996.

9. Mercan D and Malaisse WJ: Glucose-induced changes in the redox state of pancreatic non-B islet cells. Med Sci Res 24: 31-33, 1996.

10. Mercan D, Delville JP, Leclercq-Meyer V and Malaisse WJ: Preferential stimulation by $\mathrm{D}$-glucose of oxidative glycolysis in pancreatic islets: comparison between B and non-B cells. Biochem Mol Biol Int 29: 475-481, 1993.

11. Jijakli H, Rasschaert J, Nadi AB, Leclercq-Meyer V, Sener A and Malaisse WJ: Relevance of lactate dehydrogenase activity to the control of oxidative glycolysis in pancreatic islet B-cells. Arch Biochem Biophys 327: 260-264, 1996.

12. Leclercq-Meyer V, Marchand J and Malaisse WJ: Evidence for a limited role of $\mathrm{NAD}(\mathrm{P}) \mathrm{H}$ in the nutritional regulation of glucagon release: studies with menadione and $\mathrm{NH}_{4} \mathrm{Cl}$. Acta Diabetol Lat 17: 23-32, 1980.

13. Leclercq-Meyer V, Woussen-Colle MC, Lalieu C, Marchand J and Malaisse WJ: Anomeric specificity of glucose-induced somatostatin secretion. Experientia 43: 1216-1218, 1987.

14. Leclercq-Meyer V, Marchand J, Leclercq R and Malaisse WJ: Interactions of $\alpha$-ketoisocaproate, glucose and arginine in the secretion of glucagon and insulin from the perfused rat pancreas. Diabetologia 17: 121-126, 1979.

15. Hutton JC, Sener A and Malaisse WJ: The metabolism of 4-methyl-2-oxopentanoate in rat pancreatic islets. Biochem J 184: 291-301, 1979.

16. Leclercq-Meyer V, Marchand J, Woussen-Colle MC, Giroix MH and Malaisse WJ: Multiple effects of leucine on glucagon, insulin and somatostatin secretion from the perfused rat pancreas. Endocrinology 116: 1168-1174, 1985.

17. Leclercq-Meyer V and Malaisse WJ: Pulsatility of argininestimulated insulin, glucagon and somatostatin release. Med Sci Res 22: 151-154, 1984.

18. Blachier F, Leclercq-Meyer V, Marchand J, Woussen-Colle MC, Mathias PC, Sener A and Malaisse WJ: Stimulus-secretion coupling of arginine-induced insulin release. Functional response of islets to $\mathrm{L}$-arginine and L-ornithine. Biochim Biophys Acta 1013: 144-151, 1989.

19. Sener A, Conget I, Rasschaert J, Leclercq-Meyer V, Villanueva-Peñacarrillo ML, Valverde I and Malaisse WJ: Insulinotropic action of glutamic acid dimethyl ester. Am J Physiol 267: E573-E584, 1994. 
20. Leclercq-Meyer V, Marchand J and Malaisse WJ: An argininelike effect of the 'fumarate + glutamate + pyruvate' mixture on glucagon release. Life Sci 20: 1193-1198, 1997.

21. Leclercq-Meyer V, Akkan AG, Marchand J and Malaisse WJ: Effects of glimepiride and glibenclamide on insulin and glucagon secretion by the perfused rat pancreas. Biochem Pharmacol 42: 1634-1637, 1991.

22. Leclercq-Meyer V and Malaisse WJ: Opposite effects of D-glucose and 2-ketoisocaproate upon insulin release by the isolated perfused pancreas removed from hyperglycemic rats. Endocrine J 2: 265-271, 1994.

23. Marynissen G, Leclercq-Meyer V, Sener A and Malaisse WJ Perturbation of pancreatic islet function in glucose-infused rats. Metabolism 39: 87-95, 1990.

24. Malaisse WJ, Maggetto C, Leclercq-Meyer V and Sener A: Interference of glycogenolysis with glycolysis in pancreatic islets from glucose-infused rats. J Clin Invest 91: 432-436, 1993.

25. Malaisse WJ, Marynissen G and Sener A: Possible role of glycogen accumulation in B-cell glucotoxicity. Metabolism 41: 814-819, 1992.

26. Leclercq-Meyer V, Marchand J, Leclercq R and Malaisse WJ: Calcium deprivation enhances glucagon release in the presence of 2-ketoisocaproate. Endocrinology 108: 2093-2097, 1981.
27. Leclercq-Meyer V, Kadiata MM and Malaisse WJ: Effects of D-mannoheptulose and its hexaacetate ester on hormonal secretion from the perfused pancreas. Int J Mol Med 6: 143-152, 2000.

28. Leclercq-Meyer V, Kadiata MM and Malaisse WJ: Stimulation by 2-deoxy-D-glucose tetraacetates of hormonal secretion from the perfused rat pancreas. Am J Physiol 276: E689-E696, 1999.

29. Sener A, Leclercq-Meyer V and Malaisse WJ: Immediate and delayed effects of D-fructose upon insulin, somatostatin, and glucagon release by the perfused rat pancreas. Endocrine 24: 73-81, 2004.

30. Leclercq-Meyer V and Malaisse WJ: Dual mode of action of glucose pentaacetates on hormonal secretion from the isolated perfused rat pancreas. Am J Physiol 275: E610-E617, 1998.

31. Leclercq-Meyer V, Ladrière L, Fuhlendorff $J$ and Malaisse WJ: Stimulation of insulin and somatostatin release by two meglitinide analogs. Endocrine 7: 311-317, 1997.

32. Leclercq-Meyer V, Marchand J and Malaisse WJ: Insulin and glucagon release from the ventral and dorsal parts of the perfused pancreas of the rat. Effects of glucose, arginine, glucagon and carbamylcholine. Horm Res 21: 19-32, 1985. 